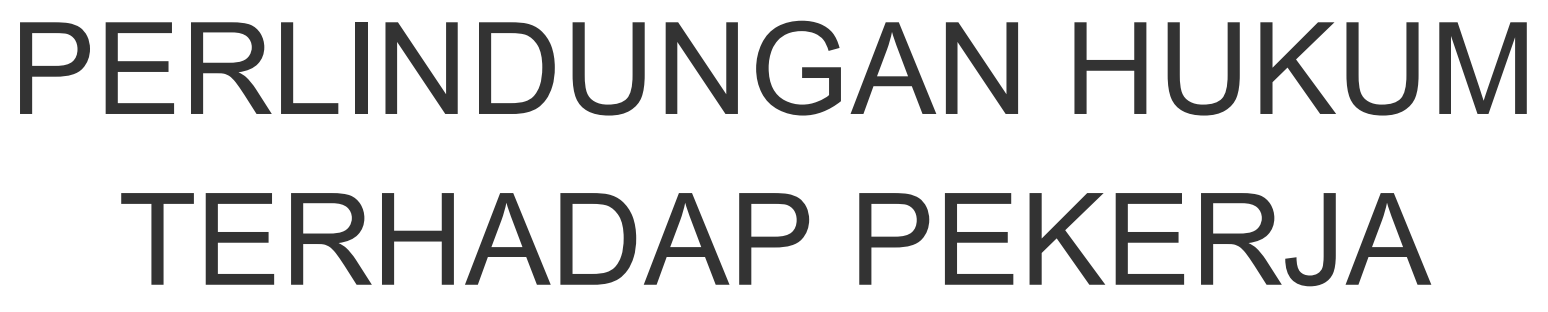

PENYANDANG DISABILITAS DI YAYASAN PUSPADI BALI by I Gede Siwananda Putra A.k

Submission date: 21-Jun-2019 05:49AM (UTC+0700)

Submission ID: 1145656235

File name: ADAP_PEKERJA_PENYANDANG_DISABILITAS_DI_YAYASAN_PUSPADI_BALI.docx (45.85K) Word count : 2786

Character count: 18486 


\title{
PERLINDUNGAN HUKUM TERHADAP PEKERJA PENYANDANG DISABILITAS DI YAYASAN PUSPADI BALI
}

\section{OLEH :}

\author{
2 I Gede Siwananda Putra A.K ${ }^{1^{*}}$ \\ Program Kekhususan Hukum Bisnis \\ Fakultas Hukum Universitas Udayana
}

\begin{abstract}
Abstrak
Didalam UU No. 13 Tahun 2003 mengenai ketenagakerjaan serta UU No. 8 Tahun 2016 mengenai penyandang disabilitas terdapat aturan perlindungan hukum. Perlindungan hukum berupa perlindung upah, jaminan sosial, fasilitas kerja, perlindungan pada tenaga kerja cacat, tenaga kerja anak, dan tenaga kerja perempuan. Untuk terciptanya perlindungan hukum agar meningkatkan kesejahteraan serta perlindungan bagi pekerja penyandang disabilitas di Puspadi Bali, hingga penting atau tidaknya untuk tahu bagaimana bentuk, pelaksanaan serta hambatan yang ada didalam yayasan itu. Riset berikut penting dilaksanakan karena perlindungan hukum untuk pekerja terlindungi oleh Perpu. Metode penelitian yang dipakai yaitu metode penelitian hukum yuridis empiris. Dari hasil riset bisa dibuat suatu simpulan bahwasannya perlindungan hukum yang telah terlaksana yaitu sistem pengupahan, istirahat atau cuti, keselamatan, kesehatan kerja, mendapatkan upah yang sama dengan tenaga kerja yang tidaklah disabilitas didalam jenis pekerjaan juga tanggung jawab yang sama, tidaklah diberhentikan karena alasan disabilitas, penempatan kerja yang adil, proporsional, serta bermartabat. Hambatan yang dihadapi tidak adanya transportasi antar jemput, serta masih minimnya akses jalan dan transportasi umum yang menunjang penyandang disabilitas.
\end{abstract}

Kata Kunci: Perlindungan, Hukum, Pekerja, Penyandang Disabilitas

${ }^{1}$ Penulis Pertama I Gede Siwananda Putra A.K adalah Mahasiswa Fakultas Hukum Universitas Udayana, Korespondensi dengan penulis melalui email: siwananda94@gmail.com. 


\section{Abstract}

In Law No. 13 of 2003 concerning manpower and Law Number 8 of 2016 concerning persons with disabilities legal protection is regulated. Regulated legal protection, such as protection of wages, social security, work facilities, protection of disabled workers, child labor, and female workers. In order to create legal protection to improve the welfare and protection of workers with disabilities in Puspadi Bali, so it is important to know how the form, implementation and obstacles contained in the foundation. This research is important because legal protection for workers is protected by statutory regulations. The research method used is a method of empirical juridical law research. 16 From the results of this study it can be concluded that the legal protection that has been implemented is the wage system, rest or leave, safety, occupational health, get the same wages as workers who are not disabled in the same type of work and responsibilities, not dismissed for reasons of disability, work placements that are fair, proportional and dignified. Constraints faced by the absence of shuttle transportation, as well as the lack of road access and public transportation that support persons with disabilities.

Keywords: Protection, Law, Workers, Persons with Disabilities

\section{1}

\section{PENDAHULUAN}

\subsection{Latar Belakang}

Pembangunan adalah satu dari sekian hal yang sangatlah vital bagi sebuah negara khususnya bagi negara berkembang. Tenaga kerja diperlukan untuk pembanguna ketenagakerjaan dalam meningkatkan kualitas masyarakat Indonesia. Sejahtera secara lahir juga batin dengan adil serta merata bagi tenaga kerja berupa perlindungan keselamatan pekerja jadi satu dari sekian faktor yang vital didalam pelaksanaan pembangunan nasional. Diperlukan kiranya sebuah sarana berlindung memelihara serta pengembangan untuk kesejahteraan, khususnya untuk siapa saja yang 
dalam proses pencarian kerja serta sesudah hubungan kerjanya berakhir. ${ }^{2}$ Secara umum perlindungan seperti menjamin setiap hak yang dipunyai oleh tenaga kerja tercantum didalam Pasal 27 ayat 2 UUD 1945 yang menyatakan, bahwasannya setiap warga negara Indonesia mempunyai hak atas pekerjaan yang selayaknya untuk kemanusiaan, dan kesamaan untuk mendapatkan kesempatan juga diperlakukan tidak diskriminasi agar mencapai kesejahteraan tenaga kerja itu sendiri maupun keluarga dengan selalu memberikan perhatian berkembangnya dunia usaha.

Sebuah pekerjaan pada kehidupan ini manusia memiliki kebutuhan yang memiliki aneka ragam hingga dapat melakukan pemenuhan kehidupan seorang butuh pekerjaan, baik itu berkerja dengan membangun usaha sendiiri ataupun bekerrja pada orang lainnya. Bekerja pada orang lainnya bisa dilaksanakan dengan bekerja pada negara yang dipanggil sebagai pegawai ataupun kerja pada orang lainnya (swata) yang dipanggil sebagaii buruh ataupun pekerja dengan memiliki pekerjaan mereka mendapatkan upah bagi biaya hidupnya. Dikarenakan bagaimana pula upah adalah sarana bagi meningkatkan kesejahteraan tenaga kerja atau karyawan. ${ }^{3}$

Begitu pula dengan penyandang disabilitas yang diberikan pekerjaan supaya bisa memberikan pemenuhan kebutuhan hidupnya mereka tidak menggantungkan hidupnya mereka pada belaskasihan orang lainnya. Bagi penyandang disabilitas membutuhkan kerja dengan alasan yang sama seperti mereka yang tidaklah mempunyai disabilitas. Penyandang disabilitas ini inginlah mendapatkan nafkah, menggunakan ketrampilan mereka, serta memberi kontribusi pada masyarakat. Tetapi beda dengan mereka yang tidaklah mempunyai disabilitas, penyandang disabilitas seringlah memperoleh hambatan didalam memanfaatkan ketrampilan di waktu mereka ingin sebuah pekerjaan. Penyandang disabilitas pula mendapat tanggapan yang tidaklah menyenangkan daripada pihak organisasi serta sesama karyawan yang merasa

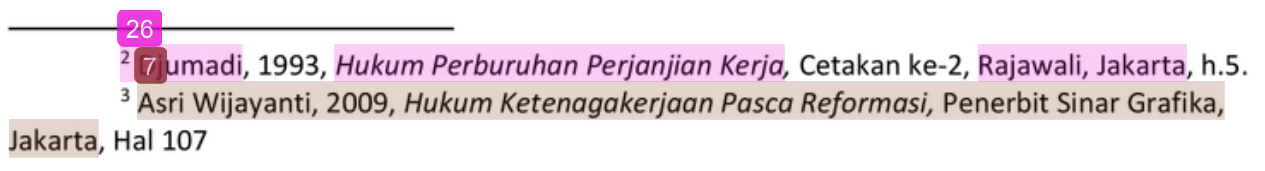


ragu dengan ketrampilan para penyandang disabilitas dalam sebuah pekerjaan serta ikut ambil andil pada kemajuan organisasi.

Penyandang disabilitas untuk sekarang sangatlah sering mendapat diskriminasi hingga para penyandang disabilitas merasa susah mendapat pekerjaan. Kesempatan kerja merupakan sebuah kondisi yang memberikan gamaran ada atau tidaknya pekerjaan yang dapat diisi pencari keria. ${ }^{4}$ Agar mewujudkan perlindungan pada tenaga kerja, pemerintah sudah menyusun UU No. 13 Tahun 2003 Tentang Ketenagakerjaan sebagai pembaruan daripada UU No. 14 Tahun 1969 Tentang Ketentuan-Ketentuan Pokok Mengenai Tenaga Kerja yang dipandang telah tidaklah cocok dengan berkembangnya masalah-masalah didalam ketenagakerjaan. Pasal 5, Seluruh tenaga kerja mempunyai kesempatan yang disamakan tidak ada diskriminasi agar mendapatkan pekerjaan, Pasal 6, Seluruh pekerja/ buruh memiliki hak mendapatkan perlakuan yang disamakan tidak ada diskriminasi daripada pemiliki usaha. Dari pasalpasal itu jelas bahwa para tenaga keria penyandang disabilitas berhak mendapatkan kerja. Dapat juga dilihat didalam UU No. 8 Tahun 2016 Mengenai Peyandang Disabilitas, Hak Pekerjaan, Kewirausahaan, dan Koperasi, Pasal 11, Hak pekerjaan, kewirausahaan, dan koperasi bagi Penyandang Disabilitas. Seorang pekerja tidaklah sekedar memiliki nilai ekonomi saja, tapi haruslah pula memiliki nilai layak sebagai manusia yang tinggi. ${ }^{5}$ Sebuah pekerjaan bisa melakukan pemenuhan seluruhnya apabila keselamatan serta kesehatan pekerja sebagai pelaksanaannya telah mendapat jaminan. ${ }^{6}$

Penulis memiliki ketertarikan dalam melaksanakan penelitian serta menulis hasil penelitian didalam sebuah karya ilmiiah yaitu skripsi yang memiliki judul "Perlindungan Hukum Terhadap Pekerja Penyandang Disabilitas Di Yayasan Puspadi Bali”.

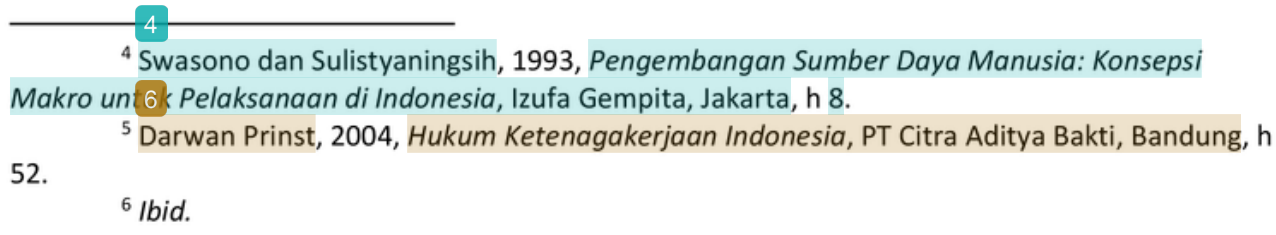




\subsection{Rumusan Masalah}

Dari semua yang sudah dikemukakan didalam latar belakang permasalahan, sehingga dapat dirumuskan beberapa masalah yang akanlah menjadi pokok bahasan didalam tulisan ini. Masalah-masalah itu bila terumuskan yaitu seperti berikut:

1. Bagaimana pelaksanaan perlindungan hukum bagi pekerja penyandang disabilitas pada Yayasan Puspadi Bali ?

2. Apakah hambatan yang dihadapi didalam pelaksanaan perlindungan hukum bagi pekerja penyandang disabilitas pada Yayasan Puspadi Bali ?

18

\section{ISI MAKALAH}

\subsection{Metode Penelitian}

Metode penelitian yang dipakai merupakan pendekatan yuridis empiris yaitu masalah dilaksanakan pengkajian dengan melaksanakan pendekatan langsung di Yayasan Puspadi Bali lalu dilakukan pengaitan dengan aturan yang ada pada perudangudangan yang berdasar kepada sebuah pengkajian normative dengan melakukan pengkajian sebuah produk hukum berdasar kepada teori-teori juga asas-asas hukum dengan langsung, supaya mendapatkan kebenaran material untuk memperoleh penyempurnaan skripsi berikut. Pendekatan empiris (hukum sebagai kenyataan sosial, kultural ataupun das sein), dikarenakan pada riset berikut dipakai data primer yang didapatkan langsung di lokasi penelitian. ${ }^{7}$

\subsection{Hasil Pembahasan}

2.2.1 Pelaksanaan Perliindungan Hukum Bagi Pekerja Penyandang Disabilitas Di Yayasan Puspadi Bali

Selain Yayasan Puspadi Bali menerima pekerja penyandang disabilitas atau yang bukan disabilitas, Yayasan Puspadi Bali juga memberdayakan pekerja disabilitas yang

\footnotetext{
${ }^{7}$ Zainuddin Ali, 2009, Metode Penelitian Hukum, Cetakan ke 4, Sinar Grafika, Jakarta, h.31-
} 32. 
ingin bekerja di tempat yang diinginkannya. Dimana semua itu sudah ada dalam anggaran dasar rumah tangga Puspadi Bali yang meliputi, asas, sifat dan fungsi.

Yayasan Puspadi Bali juga kerkolaborasi dengan D’Network suatu perusahaan non-profit yang memberikan bantuan penyandang disabilitas agar memperoleh kerja serta melakukan pengembangan ketrampilan mereka agar mendapat masa depan yang cerah.

Dimana Yayasan Puspadi Bali juga memberikan pelatihan dan pemberdayaan para penyandang disabilitas (sesuai dengan Pasal 9 mengenai pelatihan kerja UU No. 13 Tahun 2003 Tentang Ketenagakerjaan);

Pelatihan terbagi menjadii dua sebagai berikut:

1. Pelatihan kejuruan, dimana Yayasan Puspadi Bali membentuk infrastuktur yang berlanjut agar memberikan bantuan untuk penyandang disabilitas Provinsi Bali agar dapat mengetahui serta melakukan pemenuhan potensial yang ada dalam diri penyandang disabilitas ini didalam masyarakat juga pada dunia pekerjaan. Pernyataan tersebut terwujud dengan memberi kursus yang mengembangkan kepribadiannya juga profesionalitasnya dan memberi support yang dapat memberi kemungkinan para penyandang disabilitas dalam pencarian kerja serta melaksanakan langkah-langkah praktis yang diperlukan agar mandiri secara ekonomi juga memberdayakan kepribadian masingmasing.

2. Pelatihan Soft-Skill, Soft Skill menurut Berthal diartikan juga prilaku pribadi juga interpersonal yang berkembang serta memberikan maksimal kinerja seorang manusia. ${ }^{8}$ Yayasan Puspadi Bali memberikan tawaran melatih Soft Skill untuk penyandang disabilitas yang mencakupi motivasi diri, ketrampilan melakukan komunikasi, efektivitas pribadi, memecahkan permasalahan dengan kreativitas, mulai menerapakan pikiran strategik, bernegosiasi, membentuk

${ }^{8}$ Jelajah Internet, 2019, "Pentingnya Soft Skills Menurut Pakar", https://pelatihanpengembangansdm.co.id diakses tanggal 6 Februari 2019 jam 15.01 wita. 
team, serta merawat diri sendiri. Latihan-latihan tersebut diberi berbarengan dengan pelatihan kejuruan, hingga peserta memperoleh kursus pengembangan diri juga pengembangan profesionalitas yang dapat memperbesar kemungkinan para penyandang disabilitas agar melakukan pemenuhan potensial dalam diri mereka secara pribadi ataupun sebagai rakyat yang mempunyai hak yang sama. Pengalaman kerja

Memiliki keterkaitan dengan pelatihan kejuruan serta kerjasama dengan mitra organisasi, Yayasan Puspadi Bali memberikan peluang internship pada kliennya selama 3 bulan dengan intensive. Kliennya dapat bekerja sementara pada tempat yang cocok dengan keingina juga ketrampilannya. Saat program tersebut berjalan, Yayasan Puspadi Bali akanlah menanggung seluruh akomodasi juga transportasi klien ke tempat kerjanya.

Penempatan kerja

Yayasan Puspadi Bali menjadi penghubung pencari kerja dengan pemiliki usaha. Yayasan Puspadi Bali memberikan fasilitas kesempatan bekerja serta penempatan melewati penawaran kerja yang diberikan target, serta dengan memberi khursus mengembangkan kepribadian serta professional juga support yang akanlah menambah kemungkinan mereka agar melakukan pencarian kerja juga menerapkan langkahlangkah sederhana untuk mendapatkan kemandirian ekonomi.

1. Upah bagi pekerja

Menurut I Gede Ketut Sentosa sebagai asembling kursi roda, upah yang di dapatkan pekerja disabilitas atau yang bukan disabilitas mendapatkan upah yang sama yaitu sebesar Rp. 2.595.229.00, ini membuktikan bahwa tidak adanya diskriminasi upah baik pekerja disabilitas dan yang bukan disabilitas (hasil wawancara tanggal 05 Oktober 2018), sesuai dengan Pasal 11 huruf (b) 12

UU No. 8 Tahun 2016 mengenai Penyandang Disabilitas. Ini membuktikan bahwa Yayasan Puspadi Bali sudah memberikan upah yang sesuai dengan Pergub Bali No. 91 Tahun 2018 mengenaii Upah Minimmum Kabupaten /Kota yang menyatakan Upah Minimum Kabupaten/Kota (selanjutnya disebut UMK) 
Denpasar tahun 2018 sebesar Rp. 2.363.000,00. Maka Yayasan Puspadi Bali sudah cocok dengan Pasal 88 ayat 2 UU No. 13 Tahun 2003 Tentang Ketenagakerjaan yang menyatakan bahwasannya; agar terwujudnya upah yang memenuhii kehidupan yang selayaknya bagi kemanusiaaan seperti bagaimana yang tercantum didalam ayat (1), pemerintah menentukan kebijakan-kebijakan sistem upah yang melakukan perlindungan pekerja/buruh.

Upah adalah hak ekonomis bagi pekerja disabilitas ataupun yang bukan pekerja disabilitas, karena dari upah yang mereka dapatkan bisa mereka gunaka untuk kecukupan sehari - hari dan mengsejahterkan keluarga mereka.

2. Waktu istirahat atau cuti

Menurut Gede Agus Arnawa sebagai petugas lapangan, pekerja yang bekerja di Yayasan Puspadi Bali mendapat waktu istirahat pada jam 12.00 01.00 Wita. Cuti didapatkan oleh pekerja yang bekerja minimal selama 1 tahun serta cuti yang diberikan sejumlah 14 hari dalam 1 tahun, untuk pekerja laki laki diberikan cuti saat anak baru lahir selama 1 minggu sedangkan bagi perempuan mendapat cuti hamil serta melahirkan dalam 3 bulan lamanya. Hal tersebut sesuia dengan Pasal 79 UU No. 13 Tahun 2003 Tentang Ketenagakerjaan (wawancara tanggal 09 Oktober 2018). Istirahat atau cuti merupakan hak sosial yang diberikan ke pada pekerja untuk melakukan interaksi sosial antara masyarakat dan anggota keluarganya.

3. Keselamatan dan kesehatan kerja

Menurut I Made Sunarta sebagai teknisi, pekerja yang bekerja di Yayasan Puspadi Bali telah diberi jaminan keselamatan kerja yang berbentuk BPJS Kesehatan serta BPJS Ketenagakerjaan (wawancara tanggal 4 Oktober 2018), hal ini sesuai dengan Pasal 86 UU No. 13 Tahun 2003 Tentang Katenagakerjaan. Keselamatan serta kesehatan kerja merupakan hak teknik adalah hak yang meliputi berbagai usaha untuk melindungi pekerja daripada kecelakaan kerja baik saat bekerja ataupun selesai mengerjakan pekerjaannya. 


\subsubsection{Hambatan Yang Dihadapi Dalam Pelaksanaan Perlindungan hukum Bagi Pekerja}

Penyandang Disabilitas Pada Yayasan Puspadi Bali

Dimana dalam pemberian perlindungan terhadap pekerja penyandang disabilitas terdapat sekian faktor yang jadi hambatan didalam melaksanakan perlindungan hukum pada pekerja penyandang disabilitas di Yayasan Puspadi Bali seperti:

1. Menurut Ida Ayu Wiadnyani, SE sebagai Finance and Administration Manager, kendala yang di rasakan adalah mengenai masalah transportasi, karena masih minimnya sarana transportasi umum yang menunjang untuk penyandang disabilitas (hasil wawancara tanggal 15 Oktober 2018).

2. Menurut I Ketut Darma Putra sebagai Petugas Lapangan, hambatan yang dirasakan pada saat melakukan kunjungan kerja kedesa - desa karena menggunakan kaki palsu dan kurangnya akses untuk penyandang disabilitas (hasil wawancara tanggal 18 Oktober 2018). Dimana hal ini di atur dalam Pasal 5 huruf (n) UU No. 8 Tahun 2016 Tentang Penyandang Disabilitas.

3. Menurut I Gede Ketut Sentosa sebagai Asembling Kursi Roda, yang sering menghambat dalam pekerjaan masalah anak tangga karena menggunakan kursi roda (hasil wawancara tanggal 5 September 2018).

Hal ini disebabkan karena masih minimnya sarana transportasi umum dan akses jalan yang kurang menunjang untuk para disabel, sehingga menghambat pekerja penyandang disabilitas menuju tempat mereka bekerja. Selain itu pekerja penyandang disabilitas yang bekerja di Yayasan Puspadi Bali harus di tuntut untuk profesional sama seperti pekerja yang bukan merupakan pekerja disabel.

Dalam pelaksanaan perlindungan hukum sangat tergantung sikap dan praktek dari pimpinan dan karyawan. Dalam suatu yayasan seringkali dijumpai hambatan hambatan yang memperngaruhi kinerja yayasan itu sendiri. Adapun upaya - upaya yang di lakukan oleh Yayasan Puspadi Bali dalam menanggulangi hambatan/masalah terlaksananya perliindungan hukum untuk pekerja penyandang disabilitas sebagai berikut: 
1. Yayasan Puspadi Bali memberikan fasilitas sepeda motor roda tiga yang digunakan pekerja lapangan dalam kunjangan kerja, yang boleh digunakan hanya pada saat kunjungan kerja, memberikan biaya makan siang saat kunjungan kerja, memberikan fasilitas berupa laptop unutuk menunjang pekerjaan, memberikan tas, seragam, topi, biaya transportasi, perlengkapan P3K.

2. Yayasan Puspadi Bali juga menyediakan alat bantu untuk perkerja penyandang disabilitas baik berupa kaki palsu dan kursi roda.

3. Yayasan Puspadi Bali juga aktif menyuarakan tentang disabilitas dan ikut serta dalam melobi kebijakan - kebijakan, hukum dan Perundang - undangan tentang lingkungan yang bisa diakses, kesempatan yang sama dalam pendidikan, pekerjaan, termasuk dalam kehidupan sosial di dalam masyarakat.

Diharapkan dengan upaya tersebut Yayasan Puspadi Bali kedepannya dapat meningkatkan kesejahteraan pekerja penyandang disabilitas dan yang bukan merupakan penyandang disabilitas agar dapat mengatasi segala hambatan yang ada di Yayasan Puspadi Bali. Selain itu dengan adanya perlindungan akan membawa manfaat bagi pekerja itu sendiri karena mereka merasa diperhatikan sehingga memberikan motivasi terhadap pekerja agara pekerja bekerja lebih giat dan melakukan pekerjaannya lebih baik dan teliti dalam bekerja. Dengan ini pekerja membantu memajukan pembangunan pada dewasa ini dan sudah seharusnya pihak yayasan memberikan perlindungan hukum untuk menjaga pekerja sesuai yang telah di atur dalam UU No. 13 Tahun 2003 Tentang Ketenagakerjaan dan UU No. 8 Tahun 2016 Tentang Penyandang Disabilitas.

\section{PENUTUP}

\subsection{Kesimpulan}

1. Bahwa perliindungan hukum kepada pekerja penyandang disabilitas yang diberikan oleh pihak Yayasan Puspadi Bali belum sepenuhnya dilaksanakan sesuia dengan UU No. 13 Tahun 2003 Tentang Ketenagakerjaan dan UU No. 8 
Tahun 2016 Tentang Penyandang Disabiliitas. Yaitu Sistem pengupahan, Istirahat atau cuti ${ }_{8}$ Keselamatan, kesehatan kerja, mendapatkan penghasilan yang disamakan dengan tenaga kerja yang bukanlah penyandang disabilitas didalam jenis pekerjaan serta tanggung jawab yang sama, tidaklah diberhentikan karena alasan disabilitas, penempatan kerja yang adiil, proporsiional, juga bermarrtabat.

2. Adapun hambatan perlindungan hukum pekerja penyandang disabilitas di Yayasan Puspadi Bali dikarenakan tidak adanya transportasi antar jemput, karena 17 orang staff yang bekerja di Yayasan Puspadi Bali 9 orang merupakan pekerja penyandang disabilitas. Hal ini di sebabkan karena pekerja penyandang disabilitas di tuntut untuk profesional dan mandiri sama seperti pekerja yang bukan merupakan penyandang disabilitas dan sarana transport hanya diperuntukan bagi klien saja. Serta masih minimnya akses jalan dan transportasi umum yang menunjang penyandang disabilitas, dimana hal itu menyebabkan terganggunya aktivitas penyandang disabilitas.

\subsection{Saran}

Penulis memberikan saran kepada Yayasan Pusapdi Bali sebagai upaya pemecahan permasalahan penelitian agar memberikan perlindungan hukum yang sesuai dengan UU No. 13 Tahun 2003 Tentang Ketenagakerjaan dan UU No. 8 Tahun 2016 Tentang Penyandang Disabilitas yaitu:

1. Agar Yayasan Puspadi Bali menyediakan sarana transportasi antar jemput untuk pekerja penyandang disabilitas bukan untuk menghambat kemandirian penyandang disabilitas tetapi memberikan perlindungan keselamatan pekerja disabilitas untuk sampai ketempat kerja dengan selamat, apabila tidak menyediakan hal tersebut maka pihak Yayasan Puspadi Bali dapat memberikan uang sebagai ganti sarana trasportasi.

2. Agar Yayasan Puspadi Bali bekerjasama dengan Dinas Perhubungan Kota Denpasar untuk menciptakan sarana transportasi dan akses jalan yang bisa di 
akses bagi para penyandang disabilitas untuk kemudahan penyandang disabilitas melakukan aktivitasnya.

\section{DAFTAR PUSTAKA}

\section{Buku}

Asrii Wijayanti, 2009, Hukum Ketenagakerjaan Pasca Reformasi, Penerbit Sinnar Graffika, Jakarta, Hal 107

Darrwan Print, 2004, Hukum Ketenagakerjaan Indonesia, PT Citra Adiitya Bhakti, Bandung, h 52.

Djumadi, 1993, Hukum Perburuhan Perjanjian Kerja, Cetakan ke-2, Rajawali, Jakarta, h.5.

Swasono dan Sulisstyaningsih, 1993, Pengembangan Sumber Daya Manusia: Konsepsi Makro untuk Pelaksanaan di Indonesia, Isufa Gempita, Jakarta, h 8. Zainuddin Ali, 2009, Metode Penelitian Hukum, Cetakan ke 4, Sinar Grafika, Jakarta, h.31-32.

\section{Artikel}

Jelajah Internet, 2019, 'Pentingnya Soft Skills Menurut Pakar",https://pelatihanpengembangansdm.co.id diakses tanggal 6 Februari 2019 jam 15.01 wita.

3. Peraturan Perundang - undangan

Kitab Undang - Undang Hukum Perdata (Burgelijk Wetbook), diterjemahkan oleh Soedaharyo Soimin, 2011, Sinar Grafika, Jakarta. 
3

Indonesia, Undang - Undang Nomor 13 Tahun 2003 Tentang Ketenagakerjaan, Lembaran Negara Republik Indonesia Tahun 2003 Nomor 39, Tambahan Lembaran Negara Republik Indonesia Nomor 4279.

Indonesia, Undang - Undang Nomor 8 Tahun 2016 Tentang Penyandang Disabilitas, Lembaran Negara Republik Indonesia Tahun 2016 Nomor 69, Tambahan Lembar Negara Republik Indonesia Nomor 5871.

Peraturan Gubernur Bali Nomor 91 Tahun 2018 Tentang Upah Minimum Kabupaten/Kota, Lampiran Peraturan Gubernur Provinsi Bali Nomor 91 Tahun 2018. 


\section{PERLINDUNGAN HUKUM TERHADAP PEKERJA PENYANDANG DISABILITAS DI YAYASAN PUSPADI BALI}

ORIGINALITY REPORT

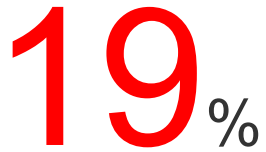

SIMILARITY INDEX

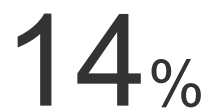

INTERNET SOURCES
$4 \%$

PUBLICATIONS
$16 \%$

STUDENT PAPERS

PRIMARY SOURCES

1 Submitted to Universitas Islam Indonesia Student Paper

2 Submitted to Udayana University Student Paper

3 docplayer.info

Internet Source

4 anzdoc.com

Internet Source

5 Submitted to Universitas Warmadewa Student Paper

6 Submitted to Universitas Muria Kudus Student Paper

7 pt.scribd.com

Internet Source

8 jdih.banjarnegarakab.go.id Internet Source 
10 Submitted to Universitas 17 Agustus 1945

Surabaya

Student Paper

11 Submitted to Universitas Jember Student Paper

12 ijds.ub.ac.id Internet Source

13 www.scribd.com Internet Source

14 eprints.uns.ac.id Internet Source

15 www.unud.ac.id Internet Source

16 indahmaharani03.blogspot.com Internet Source

17 id.123dok.com Internet Source

18 adoc.tips Internet Source 
21 Submitted to Universitas Negeri Makassar

Student Paper

22 Submitted to Universitas Negeri Surabaya The

State University of Surabaya

Student Paper

23

es.scribd.com

Internet Source

$<1 \%$

24 Submitted to Sriwijaya University

Student Paper

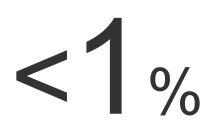

25 repository.unhas.ac.id

Internet Source

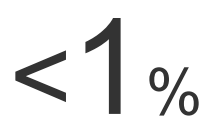

26 Submitted to iGroup

Student Paper

$<1 \%$

27 Submitted to Universitas Airlangga 